\title{
POJĘCIE STRATEGICZNYCH ZASOBÓW NATURALNYCH - UWAGI KRYTYCZNE
}

\section{'STRATEGIC NATURAL RESOURCES' - CRITICAL REMARKS}

http://dx.doi.org/10.12775/PPOS.2014.002

\section{STRESZCZENIE}

Obowiązująca od ponad dekady ustawa o zachowaniu narodowego charakteru strategicznych zasobów naturalnych kraju wprowadziła do krajowego porządku prawnego szczególną kategorię zasobów środowiska - „strategicznych zasobów naturalnych”, poddanych co do zasady szczególnemu reżimowi prawnemu. Sposób rozumienia tego

* Doktor nauk prawnych, Katolicki Uniwersytet Lubelski Jana Pawła II, Wydział Prawa, Prawa Kanonicznego i Administracji, Instytut Administracji, Katedra Prawa Zarządzania Środowiskiem.

** Magister prawa, Katolicki Uniwersytet Lubelski Jana Pawła II, Wydział Prawa, Prawa Kanonicznego i Administracji, Instytut Administracji, Katedra Prawa Zarządzania Środowiskiem. 
pojęcia, jego zakres przedmiotowy oraz relacja do innych pojęć języka prawnego i prawniczego, dotyczących zasobów środowiska nie był dotąd przedmiotem zainteresowania doktryny. Celem niniejszego opracowania jest prezentacja i wyjaśnienie podstawowych pojęć z zakresu gospodarowania zasobami środowiska i uznania ich za zasoby strategiczne kraju, wraz ze wskazaniem ratio legis oraz skutków prawnych przyjęcia takiej koncepcji jurydycznej w krajowym systemie prawa ochrony środowiska.

\section{Słowa kluczowe}

Strategiczne zasoby naturalne; narodowy charakter; usługi ekosystemów.

\section{ABSTRACT}

In 2001 a new category of legally protected resources was created by implementing the Polish Act on Preservation of the National Character of Strategic Natural Resources of the Country. The meaning, the scope and the relation to the other legal terms used in environmental law in accordance with ,strategic natural resources' was not taken into account by jurisprudence as until now; hence, a more extensive analysis of those legal terms is necessary.

In the article we deal with basic terms: strategic resources' and ,strategic natural resources', especially in the context of legal consequences resulting from that distinction.

\section{Keywords}

Strategic natural resources; national character; ecosystem services.

\section{POJĘCIE ZASOBÓW ŚRODOWISKA- UWAGI WPROWADZAJĄCE}

Pojęcie „zasoby” w odniesieniu do poddanych reglamenta1/2014 cji prawnej komponentów środowiska trafiło do języka prawnego 
i prawniczego z nauk ekonomicznych i - zwłaszcza - przyrodniczych; nie istnieje jednak definicja legalna tego pojęcia. Słownik języka polskiego PWN ${ }^{1}$ definiuje „zasoby” jako „złoża bogactw mineralnych”, a „zasób” jako „pewną ilość czegoś, zgromadzoną w celu wykorzystania w przyszłości" i w naszej ocenie ten drugi sposób definiowania unaocznia potoczny sposób myślenia o zasobach jako swoistym zapasie służącym do wykorzystania. Już z tej pobieżnej konotacji wynika więc zasadnicza konkluzja, że zasobem jest coś, co jest wykorzystywane przez człowieka, potrzebne mu aktualnie lub w przyszłości, przy czym sposób wykorzystania (gospodarczy, kulturowy, duchowy) pozostaje bez znaczenia. Taki sposób ujmowania zasobów wpływa na ich postrzeganie, ponieważ zdaniem ekolingwistów język odgrywa ważną rolę $\mathrm{w}$ postrzeganiu problemów związanych $\mathrm{z}$ ekologią i w kształtowaniu ekologicznych bądź nieekologicznych postaw wśród jego użytkowników ${ }^{2}$, a „specjalna, naczelna pozycja człowieka jest strukturalnie zawarta w systemie językowym"3, co rodzi postulat budowania krytycznej świadomości języka i skutków przyjęcia konkretnej terminologii, w tym także w wymiarze języka prawnego i prawniczego.

Przechodząc na grunt nauk prawnych, należy zacząć od konstatacji faktu, że ustawodawca posługuje się pojęciem „zasoby" w różnym kontekście, używając dodatkowych kwalifikatorów. I tak np. w ustawie z dnia 27 kwietnia 2001 r. Prawo ochrony środowiska ${ }^{4}$ przedmiotem jej regulacji prawodawca uczynił m.in. warunki korzystania z zasobów środowiska, w tym „zasady ochrony zasobów środowiska” (art. 1 zd. pierwsze oraz p. 1 p.o.ś.). Z kolei zgodnie $\mathrm{z}$ art. 1 ustawy $\mathrm{z}$ dnia 16 kwietnia 2004 r. o ochronie przyrody ${ }^{5}$ ochrona przyrody „polega na zachowaniu, zrównoważonym użytkowaniu oraz odnawianiu zasobów, tworów i składników przyrody", co pozwala

1 http://sjp.pwn.pl/szukaj/zasoby.

2 M. Steciąg, Stowa-klucze w ekologii i ich krytyka z pespektywy ekolingwistycznej, „Problemy Ekorozwoju” 2009, nr 2, s. 62.

3 Tamże.

4 Tj. Dz.U. z 2013 r., poz. 1232, dalej cytowana jako p.o.ś.

5 Tj. Dz.U. z 2013 r., poz. 627, dalej cytowana jako u.o.p. 
uznać, że wprowadza ona trzy kategorie elementów przyrody podlegających ochronie: zasoby przyrody, twory przyrody oraz jej składniki. Analiza innych przepisów prawa ochrony środowiska, np. art. 1 ust. 1 ustawy z dnia 18 lipca 2001 r. Prawo wodne $^{6}$ („zasoby wodne”), ustawy z dnia 28 września $1991 \mathrm{r}$. o lasach7 („zasoby leśne”), potwierdza tezę, że prawodawca posługuje się pojęciem „zasoby” w sposób tyleż intuicyjny, co nonszalancki.

Jednocześnie zaś już na wstępie można postawić tezę, że kategoria „zasobów” dotyczy zasobów środowiska w rozumieniu definicji ustawowej z art. 3 pkt 39 p.o.ś., a tym samym - jest kategorią zbiorczą, obejmującą rożne rodzaje zasobów ${ }^{8}$. Zgodnie z definicją ustawową środowisko obejmuje „ogół elementów przyrodniczych, w tym także przekształconych w wyniku działalności człowieka, obejmujący w szczególności powierzchnię ziemi, kopaliny, wody, powietrze, krajobraz, klimat oraz pozostałe elementy różnorodności biologicznej, a także wzajemne oddziaływanie pomiędzy tymi elementami”. Zważywszy na fakt, że katalog ten ma charakter otwarty, takiż będzie katalog pojęcia „zasoby”. Ewolucja w tym zakresie już jest obserwowana. Jeszcze do niedawna za zasób nie uznawano np. krajobrazu stanowiącego tzw. dobro wolne ${ }^{9}$, choć współcześnie status krajobrazu jako „zasobu” wprowadza jednoznacznie Europejska Konwencja Krajobrazowa, w preambule ${ }^{10}$. Współcześnie charakteru zasobów nie przypisuje się także chociażby składnikom środowiska, które nie są wykorzystywane gospodarczo (np. wodór). Nie oznacza to jednak, że wraz z rozwojem technologii nie zostaną za takie uznane w przyszłości. Równocześnie, z kategorii „zasobów środowiska” w rozumieniu p.o.ś. wykluczyć należy tzw. „stany naturalne”, tj. stan bez hałasu czy bez promieniowania elektromagnetycznego, które, choć mogą zo-

6 Tj. Dz.U. z 2012 r., poz. 1225 ze zm., dalej cytowana jako p.w.

7 Tj. Dz.U. z 2011 r. Nr 12, poz. 59 ze zm., dalej cytowana jako u.o.l.

8 Tak pod rządami ustawy o ochronie i kształtowaniu środowiska również R. Paczuski, Prawo ochrony środowiska, Bydgoszcz 2000, s. 183.

9 M. Kistowski, „Zasoby”, [w:] Encyklopedia ochrony środowiska, J. Ciechanowicz-McLean (red.), Warszawa 2009, s. 406.

10 Ustawa ratyfikująca Dz.U. z 2006 r. Nr 14, poz. 98. 
stać uznane za element środowiska, to jednak nie mogą zostać uznane za jego zasób ${ }^{11}$.

Sprawę komplikuje fakt, że pojęcie „zasoby” w języku prawniczym i prawnym jest najczęściej uzupełniane poprzez wskazanie cechy doprecyzowującej charakter czy rodzaj zasobu: „zasoby naturalne”12, „zasoby przyrodnicze”, „zasoby środowiska przyrodniczego"13 lub „zasoby środowiska naturalnego"14, nie wspominając o zwrocie języka potocznego „bogactwa naturalne". W języku prawniczym pojawiają się także pojęcia odnoszące się zbioru komponentów środowiska, np. „zasoby geosfery"15. Równolegle formułowany jest postulat zastąpienia ich wszystkich zbiorczym pojęciem „ekosystemów”16, wynikający ze słusznej refleksji nad holistycznym charakterem zasobów środowiska i niemożnością traktowania pojedynczego zasobu w oderwaniu od ochrony i gospodarczego wykorzystania pozostałych $^{17}$.

Zasoby środowiska w ujęciu nauk przyrodniczych rozumiane są jako wszystkie składniki środowiska (mające postać

11 M. Pchałek, [w:] M. Górski et al., Prawo ochrony środowiska. Komentarz, Warszawa 2011, s. 290.

12 Zdefiniowane w dyrektywie 2004/35/WE Parlamentu Europejskiego i Rady w sprawie zaradzania szkodom w środowisku i ich naprawie (Dz.Urz. UE L 178, z 30 kwietnia 2004 r., s. 66) jako „gatunki chronione i siedliska przyrodnicze, woda i ląd".

13 Zob. np. Wyrok WSA w Warszawie z dnia 10.12.2013, sygn. akt IV SA/Wa 2262/13.

14 Zob. np. M.M. Kenig-Witkowska, Międzynarodowe prawo środowiska. Wybrane zagadnienia systemowe, Warszawa 2011, s. 33.

15 Np. w podręczniku Prawo ochrony środowiska, M. Górski (red.), Warszawa 2009 , s. 440 i 545.

16 R. Olaczek, Milenijna Ocena Ekosystemów - czy nowy Raport U Thanta?, [w:] Contemporary trends of botanical research - on profesor Hanna Piotrowska 80th birthday anniversary, „Acta Botanica Cassubica”, 6/2006, s. 28, http:// www.abc.biology.ug.edu.pl/userfiles/abc6/abc6_02.pdf [21.02.2014]

17 Relację tę dostrzeżono już w Średniookresowej Strategii Rozwoju Kraju, zgodnie z którą: „Ważnym elementem spójności terytorialnej jest dbałość o zasoby przyrodnicze, w tym utrzymanie pełnej funkcjonalności ekosystemów. Dotyczy to zarówno poprawy infrastruktury, jak i uwzględniania potrzeb zrównoważonego zarządzania środowiskiem w procesach rozwojowych". Zob. Uchwała Rady Ministrów nr 157 z 25 września 2012 r. w sprawie przyjęcia Strategii Rozwoju Kraju 2020, M.P. Nr 212, poz. 882. 
energii oraz materii nieożywionej lub ożywionej), z których korzysta osobnik (populacja, gatunek) podczas swojego życia ${ }^{18}$. Nauki społeczne zaś, ze swej natury antropocentryczne ${ }^{19}$, definiują zasoby jako składniki przyrody (substancje i energie) wykorzystywane w procesie produkcji społecznej dla zaspokojenia materialnych i duchowych potrzeb społeczeństwa ${ }^{20}$. Z kolei w naukach ekonomicznych dominuje tzw. ekonomiczne ujęcie zasobów, rozumianych jako wszelkie zasoby środowiska nadające się do wykorzystania w ramach działalności gospodarczej lub takie, których gospodarcze wykorzystanie jest opłacalne w warunkach dostępnej $\mathrm{w}$ danym czasie techniki oraz wynikającej z niej relacji kosztów i zysków ${ }^{21}$.

Ten krótki przegląd prezentowanych w nauce stanowisk, nie wyczerpując ze swej istoty całości zagadnienia, sygnalizuje dostrzegalną różnorodność zarówno w wymiarze czysto terminologicznym, jak i bogactwo definicji. Próbując zniwelować tę różnorodność, przyjmujemy, że na potrzeby niniejszego opracowania będziemy się posługiwali pojęciem „zasobów środowiska" - o ile mowa o zbiorczym ujęciu zasobów - w ujęciu nauk społecznych. Takie ujęcie obejmuje naszym zdaniem pozostałe definicje, kładąc także nacisk na aspekt aksjologiczny ${ }^{22}$ stanowiący uzasadnienie regulacji ustawowej - poddanie zasobów reglamentacji prawnej następuje bowiem z uwagi na potrzeby człowieka. Dotyczy to zarówno reglamentacji dostępu do zaso-

18 M. Kistowski, „Zasoby środowiska”, s. 406.

19 Jak zauważa A. Giddens, „W analizach strukturalnych w obrębie nauk społecznych relacje przyczynowe, które znajdują wyraz w generalizacjach teoretycznych, nie odnoszą się do mechanicznych zależności stwierdzonych w naturze, ale do rezultatów działań ludzi", A. Giddens, Nowe zasady metody socjologicznej, Kraków 2001, s. 217.

20 M. Kistowski, „Zasoby środowiska”, s. 406.

21 Encyclopedia PWN, http://encyklopedia.pwn.pl/haslo/4000548/zasoby-naturalne.html.

22 Rozwinięcie tego wątku zob. B. Scheuer, Aksjologiczny kontekst ekonomicznych problemów gospodarowania zasobami środowiskowymi, [w:] Zrównoważony rozwój - doświadczenia polskie i europejskie, J. Czaja (red.), Nowa Ruda 2005, s. 402 i n, zob. także publikacje zebrane w zbiorze Humanistyczne, ekonomiczne i ekologiczne aspekty kategorii „rozwój”, „Zeszyty Naukowe Komitetu »Człowiek i Środowisko« przy prezydium PAN" 2005, z. 40, passim. 
bów rzadkich i cennych, których ochrona ważna jest z punktu widzenia potrzeb estetycznych i duchowych czy zachowania różnorodności biologicznej, jak i reglamentacji dokonywanej z uwagi na rolę i znaczenie zasobów w procesie produkcji społecznej, a więc ich gospodarczego wykorzystania.

Tak uzasadnione uwagi terminologiczne pozwalają na przejście do analizy zagadnienia kwalifikowania zasobów środowiska w sposób jakościowy, jako zasobów „strategicznych”.

\section{2. „STRATEGICZNE ZASOBY NATURALNE” W UJĘCIU USTAWY 0 ZACHOWANIU NARODOWEGO CHARAKTERU STRATEGICZNYCH ZASOBÓW NATURALNYCH KRAJU}

Jak wynika z art. 1 ustawy z dnia 6 lipca 2001 r. o zachowaniu narodowego charakteru strategicznych zasobów naturalnych $\mathrm{kraju}^{23}$, do strategicznych zasobów naturalnych kraju zalicza się pięć kategorii zasobów, stanowiących przedmiot regulacji różnych ustaw z zakresu prawa ochrony środowiska. Należą do nich przede wszystkim zasoby wodne, obejmujące wody podziemne oraz wody powierzchniowe w ciekach naturalnych i w źródłach, z których te cieki biorą początek, w kanałach, w jeziorach i zbiornikach wodnych o ciągłym dopływie w rozumieniu ustawy Prawo wodne. Pojęcie „wód podziemnych” musi być interpretowane zgodnie z art. 9 pkt 22 p.w., zgodnie z którym przez wody podziemne rozumie się „wszystkie wody znajdujące się pod powierzchnią ziemi w strefie nasycenia, w tym wody gruntowe pozostające w bezpośredniej styczności z gruntem lub podglebiem". Z kolei kategoria pojęciowa „wód powierzchniowych" odpowiada terminologii przyjętej w art. 5 p.w., obejmując śródlądowe wody powierzchniowe, stanowiące wody płynące w rozumieniu art. 5 ust. 3 pkt 1 lit. a-b p.w. Na tle analizy

23 Dz.U. z 2001 r. Nr 97, poz. 1051 ze zm., dalej cytowana jako ustawa o zachowaniu narodowego charakteru. 
przepisu art. 1 pkt 1 ustawy o zachowaniu narodowego charakteru i art. 5 p.w. powstaje jednak pytanie, czy pojęcie „wód powierzchniowych" z tej pierwszej ustawy obejmuje także śródlądowe wody powierzchniowe „znajdujące się w sztucznych zbiornikach wodnych usytuowanych na wodach płynących". Artykuł 1 ustawy o zachowaniu narodowego charakteru stanowi bowiem o „zbiornikach wodnych o ciągłym dopływie”, a art. 5 ust. 3 pkt 3 p.w. o „sztucznych zbiornikach wodnych usytuowanych na wodach płynących". Jak podnosi się w literaturze, to drugie pojęcie odnosi się do zbiorników wodnych „potocznie zwanych zalewami służącymi do celów rekreacji, sportów wodnych i wędkowania"24, a art. 5 ust. 3 pkt 1 lit. b) p.w. wyodrębnia kategorię ,innych naturalnych zbiorników wodnych o ciągłym bądź okresowym naturalnym dopływie lub odpływie wód powierzchniowych". Z kolei z orzecznictwa a contrario wynika, że ,jezioro stanowi zbiornik naturalny" ${ }^{25}$. Należy więc uznać, że pojęcie „zbiornika wodnego o ciągłym dopływie” jest pojęciem zbiorczym, obejmującym zbiorniki sztuczne oraz naturalne, o ciągłym dopływie.

Artykuł 1 ust. 1 ustawy o zachowaniu narodowego charakteru wyłącza z przynależności do strategicznych zasobów naturalnych wody stojące, które zgodnie z art. 5 ust. 3 pkt 3 p.w. obejmują wody znajdujące się w jeziorach oraz innych naturalnych zbiornikach wodnych niezwiązanych bezpośrednio, w sposób naturalny, z powierzchniowymi wodami płynącymi (np. w stawach czy oczkach wodnych).

Druga kategoria strategicznych zasobów naturalnych kraju obejmuje wody polskich obszarów morskich wraz z pasmem nadbrzeżnym i ich naturalnymi zasobami żywymi i mineralnymi, a także zasobami naturalnymi dna i wnętrza ziemi znajdującego się w granicach tych obszarów w rozumieniu ustawy z dnia 21 marca 1991 r. o obszarach morskich Rzeczypospolitej Polskiej i administracji morskiej ${ }^{26}$. Przez pojęcie „wód polskich

24 J. Szachułowicz, Prawo wodne. Komentarz, Warszawa 2007, s. 39.

25 Wyrok WSA w Poznaniu z dnia 2009.12.16, sygn. akt III SA/Po 765/09, LEX nr 550175.

26 Tj. Dz.U. z 2013 r., poz. 93, dalej cytowana jako u.o.m. 
obszarów morskich" ustawa o obszarach morskich rozumie morskie wody wewnętrzne, morze terytorialne oraz wyłączną strefę ekonomiczną (art. 2 ust. 1 u.o.m.), a zwierzchnictwo terytorialne Rzeczypospolitej Polskiej nad morskimi wodami wewnętrznymi i morzem terytorialnym rozciąga się na wody, przestrzeń powietrzną nad tymi wodami oraz na dno morskie wód wewnętrznych i morza terytorialnego, a także na wnętrze ziemi pod nimi (art. 2 ust. 3 u.o.m.). Z kolei przez pojęcie „pas nadbrzeżny” (tj. pas przebiegający „wzdłuż wybrzeża morskiego" - art. 36 ust. 3 u.o.m.) ustawa ta rozumie pas techniczny stanowiący strefę wzajemnego bezpośredniego oddziaływania morza i lądu; jest on obszarem przeznaczonym do utrzymania brzegu w stanie zgodnym z wymogami bezpieczeństwa i ochrony środowiska; oraz pas ochronny obejmujący obszar, w którym działalność człowieka wywiera bezpośredni wpływ na stan pasa technicznego (art. 36 ust. 2 u.o.m.).

Tym samym należy uznać, że zakres przedmiotowy ochrony w tej kategorii został ukształtowany bardzo ciekawie, obejmując (w odróżnieniu od wymienienia ulokowanego w art. 1 pkt 1) także „naturalne zasoby żywe i mineralne, a także zasoby naturalne dna i wnętrza ziemi" znajdujące się w granicach tych obszarów (np. piasek czy bursztyn). W odniesieniu do niego, po pierwsze, podnieść należy, że sformułowanie „naturalne zasoby żywe" obszarów morskich i pasa nadbrzeżnego jest pojęciem szerszym niż używane w ustawie o rybołówstwie morskim ${ }^{27}$ sformułowanie „zasoby żywe morza”. To ostatnie obejmuje bowiem dostępne, żywe morskie gatunki wodne, w tym gatunki anadromiczne i katadromiczne $\mathrm{w}$ fazie życia $\mathrm{w}$ morzu $^{28}$; pojęcie zaś naturalnych zasobów żywych wód polskich obszarów morskich wraz z pasmem nadbrzeżnym obejmuje lege non distinguente także organizmy żywe powiązane z tymi obszarami, np. gatunki

27 Dz.U. z 2004 r., Nr 62, poz. 574 ze zm.

28 Rozporządzenie Parlamentu Europejskiego i Rady nr 1380/2013 w sprawie wspólnej polityki rybołówstwa, zmieniające Rozporządzenia Rady nr 1954/2003 i 1224/2009 oraz uchylające rozporządzenia Rady nr 2371/2002 i 639/2004 oraz decyzję Rady 2004/585/WE, Dz.Urz. UE L nr 354 z 2013, s. 86. 
tam gniazdujących ptaków. Ze swej istoty zasoby te wykazują cechę zasobów labilnych (zwłaszcza gatunki ryb morskich wpływających do zbiorników słodkowodnych - łosoś, sandacz), co sprawia, że przymiot „zasobów strategicznych” uzyskują one wyłącznie na tych obszarach i tracą go poza granicą pasa nadbrzeżnego czy polskich obszarów morskich. Takie rozwiązanie prawne trudno uznać za racjonalne. Po drugie, do zasobów strategicznych będą należały „minerały” zakwalifikowane do strategicznych na innej podstawie prawnej niż pozostałe kopaliny regulowane ustawą z dnia 9 czerwca 2011 r. Prawo geologiczne i górnicze ${ }^{29}$, a objęte tym statusem w trybie art. 1 pkt 4 ustawy o zachowaniu narodowego charakteru (o czym mowa poniżej).

Skutkiem takiego ukształtowania art. 1 pkt 1-2 ustawy o zachowaniu narodowego charakteru jest fakt, że zasoby żywe polskich obszarów morskich stanowią zasoby strategiczne - inaczej niż zasoby żywe wód śródlądowych regulowane przepisami ustawy z dnia 18 kwietnia 1985 r. o rybactwie śródlądowym ${ }^{30}$.

Trzecią kategorię strategicznych zasobów naturalnych kraju stanowią „lasy państwowe”. Pojęcie to jest pojęciem języka potocznego, pozbawionym desygnatu w ustawie o lasach - domniemywać należy, że chodzi tu o grunty leśne będące własnością Skarbu Państwa, które co do zasady zarządzane są przez Państwowe Gospodarstwo Leśne Lasy Państwowe (w ustawie o lasach zwane dalej „Lasami Państwowymi” - wniosek z art. 4 ust. 1 u.o.l.). Jednakże założenie to wywołuje niezwykle ciekawe implikacje prawne, ponieważ zgodnie $\mathrm{z}$ art. 4 ust. 2 u.o.l. jej ust. 1 nie stosuje się do lasów: będących w użytkowaniu wieczystym parków narodowych; wchodzących w skład Zasobu Własności Rolnej Skarbu Państwa oraz będących w użytkowaniu wieczystym na mocy odrębnych przepisów. Czy w praktyce oznacza to, że te zasoby leśne nie będą należały do kategorii „strategicznych zasobów naturalnych kraju”? Twierdząca odpowiedź na to pytanie jest możliwa przy przyjęciu powyższego założenia, że przez pojęcie „lasy państwowe” rozumiemy zasoby leśne stanowiące własność Skarbu Państwa. Jednocześnie jed- 
nak zasoby leśne przekazane w użytkowanie wieczyste parkom narodowym, jako ich „zasoby przyrodnicze”, będą uznane za strategiczne zasoby naturalne na podstawie art. 4 pkt 5 ustawy o zachowaniu narodowego charakteru.

Kolejną - czwartą kategorię strategicznych zasobów naturalnych stanowią „złoża kopalin niestanowiące części składowych nieruchomości gruntowej w rozumieniu ustawy z dnia 4 lutego 1994 r. Prawo geologiczne i górnicze ${ }^{31}$, która utraciła moc z dniem 1 stycznia 2012 r. Wykładnia systemowa nakazuje uznać, że w sytuacji, gdy ustawodawca nie wskazuje na akt prawny w sposób precyzyjny, lecz rodzajowy, chodzi o akt prawny aktualnie obowiązujący, zaś w przypadku gdy „powołany precyzyjnie akt prawny utracił moc, przepis odwołujący traci aktualność" 32 . Jednocześnie zaś, zgodnie z przepisem końcowym (art. 225 p.g.g.) „ilekroć w obowiązujących przepisach jest przywołana ustawa, o której mowa w art. 226, należy przez to rozumieć niniejszą ustawę". Ustawą powołaną w art. 226 jest ustawa Prawo geologiczne i górnicze z 1994 r. Brak jednak w aktualnie obowiązującym desygnatu pojęcia „złoża kopalin niestanowiące części składowych nieruchomości gruntowej", aktualnie obowiązująca ustawa p.g.g. posługuje się bowiem kryterium przedmiotowym, wymieniając w art. 10 ust. 1 i 2 te kategorie kopalin, które objęte są własnością górniczą. Należą do nich: „złoża węglowodorów, węgla kamiennego, metanu występującego jako kopalina towarzysząca, węgla brunatnego, rud metali z wyjątkiem darniowych rud żelaza, metali w stanie rodzimym, rud pierwiastków promieniotwórczych, siarki rodzimej, soli kamiennej, soli potasowej, soli potasowo-magnezowej, gipsu i anhydrytu, kamieni szlachetnych, bez względu na miejsce ich występowania". Własnością górniczą są objęte także złoża wód leczniczych, wód termalnych i solanek, a pozostałe złoża kopalin objęte zostały prawem własności nieruchomości gruntowej na podstawie art. 10 ust. 3 p.g.g. Stosując wykładnię systemową, należy więc uznać, że „złoża kopalin niestano-

31 Tj. Dz.U. z 2005 r. Nr 228, poz. 1947 ze zm.

32 B. Rakoczy, [w:] Z. Bukowski et al., Prawo ochrony środowiska. Komentarz, Warszawa 2013, s. 122. 
wiące części składowych nieruchomości gruntowej" to kopaliny wymienione wprost $\mathrm{w}$ art. 10 ust. 1 i 2 p.g.g., czyli nieobjęte prawem własności nieruchomości gruntowej i tylko im należny będzie status „strategicznych zasobów naturalnych”.

Ostatnią kategorię strategicznych zasobów naturalnych kraju stanowią „zasoby przyrodnicze parków narodowych”. Powrót do przepisów u.o.p. wywołuje jeszcze większy chaos terminologiczny, zważywszy na fakt, że sama u.o.p. używa zarówno pojęcia „zasoby przyrody”, jak i „zasoby przyrodnicze” (zob. np. art. 8h ust. 1 pkt 13 u.o.p.). Ponadto, w przepisach systemu prawa ochrony środowiska nader często stosowane jest również nawiązujące do tych pojęć określenie „elementy przyrodnicze”. W tym względzie doktryna podnosi, że pomimo braku legalnej definicji tego pojęcia z elementami przyrodniczymi powinny być utożsamiane wszystkie składniki środowiska przyrodniczego, definiowanego jako „krajobraz wraz z tworami przyrody nieożywionej oraz naturalnymi i przekształconymi siedliskami przyrodniczymi i występującymi na nich roślinami, zwierzętami i grzybami" (art. 5 pkt 20 u.o.p.) ${ }^{33}$. Z powyższych względów, przy ustalaniu istoty pojęcia „zasoby przyrodnicze parków narodowych", pomocna może się okazać regulacja art. 8 u.o.p., określającego cele powołania i przedmiot ochrony parku narodowego, zgodnie z którym „1. Park narodowy obejmuje obszar wyróżniający się szczególnymi wartościami przyrodniczymi, naukowymi, społecznymi, kulturowymi i edukacyjnymi, o powierzchni nie mniejszej niż 1000 ha, na którym ochronie podlega cała przyroda oraz walory krajobrazowe. 2. Park narodowy tworzy się w celu zachowania różnorodności biologicznej, zasobów, tworów i składników przyrody nieożywionej i walorów krajobrazowych, przywrócenia właściwego stanu zasobów i składników przyrody oraz odtworzenia zniekształconych siedlisk przyrodniczych, siedlisk roślin, siedlisk zwierząt lub siedlisk grzybów”. Oznacza to, że ochronie na obszarze parku narodowego podlegają „cała przyroda”, którą - jak sądzimy można uznać za równoważnik „zasobów przyrodniczych” oraz

33 Zob. K. Gruszecki, Prawo ochrony środowiska. Komentarz, Warszawa 2008, s. 94. 
krajobraz. Przyjęcie takiego założenia wiąże się jednak z dostrzeżeniem braku racjonalności prawodawcy, który nie powinien tego samego przedmiotu ochrony określać dwoma pojęcia$\mathrm{mi}^{34}$. Wychodząc $\mathrm{z}$ tego założenia i poddając interpretacji zakres przedmiotu ochrony w parku narodowym („cała przyroda oraz walory krajobrazowe”) w kontekście sformułowania „zasoby przyrodnicze parków narodowych", stosując wykładnię językową, należy uznać, że zasoby krajobrazowe per se nie mogą zostać uznane za strategiczny zasób naturalny kraju ${ }^{35}$. Z drugiej strony nie ulega wątpliwości, że w części przypadków o substracie materialnym krajobrazu na obszarze parku narodowego mogą przesądzać zasoby strategiczne w ujęciu ustawy o zachowaniu narodowego charakteru.

Rozliczne zastrzeżenia wynikające z łącznej interpretacji przepisów ustawy o zachowaniu narodowego charakteru oraz ustaw sektorowych sprawiają, że ocena jakości tego aktu prawnego jest niska, jego stosowanie rodzi bowiem szereg wątpliwości interpretacyjnych. Nie ulega jednak wątpliwości, że ustawa ta wprowadziła „nową koncepcję jurydyczną" ${ }^{36}$, ustanawiając szczególną kategorię zasobów środowiska, którymi są „strategiczne zasoby naturalne". Pojawia się jednak pytanie o cel przyjęcia tej regulacji. Stosując argumentację związaną z ratio legis, należy założyć, że z jakichś przyczyn trzeba było nadać określonym zasobom rangę szczególną, związaną z ich „strategicznym” charakterem.

34 Zob. §10 rozporządzenia Prezesa Rady Ministrów z dnia 20 czerwca 2002 r. w sprawie „Zasad techniki prawodawczej”, Dz.U. z 2002 r., Nr 100, poz. 908.

35 Jednak wykładnia systemowa, uwzględniająca ochronę obszarów cennych kulturowo (krajobrazu kulturowego, na który składają się przecież elementy przyrodnicze), jak i postanowienia Europejskiej Konwencji Krajobrazowej uznającej krajobraz za zasób środowiska, może nasuwać na tyle istotne wątpliwości, że wymagać one będą w efekcie jednoznacznego rozstrzygnięcia w drodze działalności legislacyjnej ustawodawcy.

36 W. Radecki, Prawo łowieckie. Komentarz, Warszawa 2007, s. 49. 


\section{UZASADNIENIE WYODRĘBNIENIA KATEGORII NORMATYWNEJ „STRATEGICZNE ZASOBY NATURALNE”}

Samo słowo „strategiczny”, wg słownika języka polskiego PWN ${ }^{37}$, oznacza „bardzo ważny z jakichś względów”, a także „dotyczący strategii wojennej” lub „związany z długoterminowymi działaniami, mającymi doprowadzić do określonego celu". Należy uznać, że pierwsze i trzecie rozumienie wprost odnosi się do „strategicznych zasobów naturalnych kraju”, które są istotne z uwagi na rolę, jaką odgrywają dla całości społeczeństwa i jednocześnie z uwagi na fakt, że powinny być one dostępne w sposób długoterminowy. Marginalnie tylko wspomnieć należy, że zachowanie naturalnego charakteru zasobów np. leśnych mogło mieć znaczenie w czasach dawniejszych, gdy stanowiły one barierę w przypadku działań wojennych, lecz współcześnie, z uwagi na rozwiniętą technikę wojskową i rozwój technologii, zasoby te nie mają już takiego znaczenia; ten sposób rozumienia pojęcia „strategiczne” należy więc pozostawić na uboczu.

Pojawia się jednak pytanie, czy faktycznie te kategorie zasobów, które uznane zostały za strategiczne przez prawodawcę, po pierwsze, spełniają kryteria bycia „strategicznymi”, oraz czy prawodawcy nie umknęły inne zasoby o takiej samej lub nawet ważniejszej roli. Ocenę tę należy sformułować w kontekście tzw. funkcji ekosystemów, do których należą: funkcja zaopatrzeniowa (żywność, woda, drewno, włókna), funkcje regulacyjne (zapewniające regulację klimatu i opadów, zjawisk hydrologicznych) oraz kulturowe (piękno, rekreacja, inspiracja) i wspomagające (tworzenie gleby, fotosynteza oraz obieg składników pokarmowych) ${ }^{38}$. Odnosząc się do zasobów wodnych w rozumieniu art. 1 ust. 1 ustawy o zachowaniu narodowego charakteru, należy uznać, że bez wątpienia są one zasobami niezbęd-

37 http://sjp.pwn.pl/szukaj/strategiczny, [24.02.2014].

38 Produkcje i funkcje ekosystemu, Komisja Europejska, wrzesień 2009, http://ec.europa.eu/environment/pubs/pdf/factsheets/Eco-systems\%20 goods\%20and\%20Services/Ecosystem_PL.pdf [18.02.2014] 
nymi zarówno dla funkcjonowania społeczeństwa (na potrzeby gospodarstwa domowego, rekreacji i wypoczynku oraz uprawiania sportów), jak i jako korytarze transportowe, a także jako środowisko życia innych organizmów. Pełnią więc one zarówno funkcje zaopatrzeniowe, regulacyjne, kulturowe, jak i wspomagające. Podobnie wszystkie te funkcje pełnią wody polskich obszarów morskich (poza funkcją zaopatrzeniową jako woda pitna - aktualnie, lecz z chwilą opracowania tanich technologii odsalania wód morskich mogą ją zacząć pełnić). Podobnie zasoby leśne, dla których funkcja zaopatrzeniowa i regulacyjna (zapobieganie powodziom i suszom, regulacja klimatu i obiegu wody w środowisku) wysuwają się na plan pierwszy jako najważniejsze. Z kolei zasoby przyrodnicze parków narodowych pełnią przede wszystkim funkcję kulturową, choć w związku z faktem, że nie obejmują one zasobów krajobrazowych - jest to kwestia dyskusyjna. Na pewno pełnić mogą funkcję regulacyjną, i wspomagającą, a z uwagi na zakazy obowiązujące $\mathrm{w}$ parku narodowym - nie mogą pełnić funkcji zaopatrzeniowej.

Kopaliny z kolei trudno oceniać pod kątem realizowania przez nie funkcji ekosystemowych, z uwagi na fakt, że nie mieszczą się one w pojęciu ekosystemów, które z definicji odnoszą się do „układów strukturalno-funkcjonalnych łączących żywą przyrodę z nieożywionymi składnikami"39. Gdyby jednak chcieć wskazać funkcje ogólne, których realizacji służy wydobywanie kopalin, to niewątpliwie pełnią one funkcję zaopatrzeniową i to najczęściej w sposób jednorazowy (jako zasoby nieodnawialne nadają się one co do zasady wyłącznie do jednorazowego użycia, najczęściej w procesie spalenia, wyjątkiem są zasoby rud metali szlachetnych, jak platyna czy złoto, które mogą być wykorzystywane wielokrotnie po ich wydobyciu). Niemniej nie można pominąć faktu, że funkcja ta stanowi podstawę współczesnej gospodarki światowej ${ }^{40}$, opartej na spalaniu

39 R. Olaczek, Milenijna, s. 27.

40 Zwanej „brązową gospodarką”. Więcej zob. B. Ryszawska, Zielona gospodarka - teoretyczne podstawy koncepcji i pomiar jej wdrażania $w$ Unii Europejskiej, Wrocław 2013, s. 74 i n. 
paliw kopalnych. Nie można jednak nie dostrzegać także innego faktu, a mianowicie, że złoża kopalin eksploatowane i możliwe do eksploatacji w Polsce stanowią zaledwie odsetek kopalin wykorzystywanych przez polską gospodarkę, uznanie ich za „strategiczne" nijak ma się także do ocen ekonomicznej opłacalności ich wydobycia ${ }^{41}$.

Wszystkie wyżej wymienione funkcje pełni także różnorodność biologiczna, rozumiana jako zróżnicowanie wszystkich żywych organizmów występujących na Ziemi w ekosystemach lądowych, morskich i słodkowodnych oraz w zespołach ekologicznych, których są częściąa ${ }^{42}$, która jednak z niewiadomych przyczyn nie stała się przedmiotem regulacji ustawy o zachowaniu narodowego charakteru. Stanowi ona najistotniejszy zasób strategiczny, z jakim ludzkość w ogóle ma do czynienia, z uwagi na rolę, którą pełni (bez niej niemożliwe byłoby pełnienie przez zasoby środowiska jakiejkolwiek innej funkcji ekosystemowej, a więc ją należy uznać za niezbędny warunek życia ludzi) oraz ze względu na rzadkość występowania poszczególnych elementów różnorodności biologicznej czy zagrożenie jej utratą. Brak uznania jej za zasób strategiczny kraju należy uznać za zasadniczy błąd ustawodawcy i postulować, jako uwagę de lege feren$d a-$ jej objęcie regulacją ustawową na tym samym poziomie, zwłaszcza że konwencja o różnorodności biologicznej posługuje się pojęciem zasobów, w odniesieniu do zasobów biologicznych. Zgodnie z art. 2 konwencji obejmują one „zasoby genetyczne, organizmy i ich części, populacje i jakiekolwiek inne żywe ele-

41 Stan ten zdefiniowano w Strategii Przestrzennego Zagospodarowania Kraju 2030 uznając, że „Polska jest poważnym producentem surowców mineralnych, mimo że w ostatnich dziesięcioleciach wykorzystanie kopalin ulegało ograniczaniu ze względu na wyeksploatowanie najbardziej dostępnych złóż, rosnące koszty eksploatacji oraz kolizje z innymi elementami zagospodarowania przestrzennego. Jednocześnie wzrosło znaczenie braku akceptacji społecznej dla powodujących negatywne skutki dla środowiska metod wydobycia kruszyw budowlanych i pozostałych kopalin", zob. uchwała nr 239 Rady Ministrów w sprawie przyjęcia Strategii Przestrzennego Zagospodarowania Kraju 2030, M.P. 2012, poz. 252.

42 Konwencja o różnorodności biologicznej, ratyfikowana przez Polskę 13 grudnia 1995 r., Dz.U. z 2002 r., Nr 184, poz. 1532 i 1533. 
menty ekosystemu, które faktycznie lub potencjalnie mogą być wykorzystywane lub stanowić mogą wartość dla ludzkości”.

\section{PODSUMOWANIE}

Z uwagi na różnorodność zasobów objętych regulacją prawną jako zasoby strategiczne, a także wykluczenie pewnych kategorii zasobów z tej koncepcji, pomimo spełniania przez nie funkcji rozumianych jako usługi środowiskowe, należy uznać, że omawiana regulacja nie spełnia wymogów, jakie stawiamy przed racjonalnym prawodawcą. W literaturze przedmiotu wskazuje się, że ratio legis tej regulacji stanowiły próby zabezpieczenia przed niekorzystnymi przekształceniami własnościowymi (prywatyzacją) PGL „Lasy Państwowe”, lecz zakres ustawy jest przecież znacznie szerszy, odnosząc się także do innych kategorii zasobów, a wzmiankowane pobudki można uznać za mające charakter $\mathrm{w}$ znacznej mierze ideowy ${ }^{43}$, co podkreśla sam tytuł ustawy, wskazujący jako cel regulacji „zachowanie narodowego [podkreślenie nasze] charakteru strategicznych zasobów naturalnych kraju”, choć doktryna podkreśla, że „status narodowego charakteru zasobów nie pociąga za sobą dalszych konsekwencji natury prawnej" ${ }^{4}$. O tym, że problem ten nie wybrzmiał do dnia dzisiejszego świadczy inicjatywa partii koalicyjnych - PO i PSL z 12 stycznia 2014 r. dotycząca zmiany Konstytucji RP pod kątem wpisania do jej art. 74 postano-

43 Zob. np. A. Śliwiński, Co się dzieje z polskimi zasobami naturalnymi?, „Biuletyn Europejskiego Monitora Ekonomicznego” nr 9/2009, http:// www.monitor-ekonomiczny.pl/s17/Artyku\%C5\%82y/a74/Co_dzieje_si\%C4\%99_z_polskimi_zasobami_naturalnymi_html [22.02.2014]: „z nieukrywanym zażenowaniem musimy tutaj wypowiadać banalną prawdę, iż rząd nie ma żadnego mandatu do wyzbywania się bogactw naturalnych, tak jak nie ma mandatu do wprowadzenia niewolnictwa. Nie jest to porównanie metaforyczne, ponieważ oddanie bogactw naturalnych w obce ręce równa się oddaniu kraju w niewolę".

44 B. Rakoczy, Funkcjonowanie leśnych regulacji prawnych $w$ układach międzysektorowych, „Przegląd Prawa Ochrony Środowiska” 2013, nr 4, s. 13. 
wień dotyczących zakazu przekształceń własnościowych (czyli prywatyzacji) PGL „Lasy Państwowe”45. Postulat ten był także formułowany w literaturze przedmiotu przez B. Rakoczego, który uznaje, że taka regulacja „wzmocniłaby publicznoprawny charakter zasobów przyrody i konieczność jej wzmożonej ochrony z uwagi na właśnie publicznoprawny charakter"46. Potwierdza to z jednej strony słabość ustawy o zachowaniu narodowego charakteru, która zawiera analogiczne postanowienia (w art. 2, który stanowi, że strategiczne zasoby naturalne stanowiące własność Skarbu Państwa co do zasady nie podlegają przekształceniom własnościowym), a z drugiej - w sposób oczywisty uruchamia dalsze pytania o uzasadnienie ideowe i czysto polityczne inicjatywy klubów parlamentarnych. Podobny problem widoczny był w kontekście poszukiwania (i przyszłego wydobywania) gazu łupkowego przez koncerny zagraniczne. Przykład ten dobitnie ukazuje słabość koncepcji "strategicznych zasobów naturalnych", ponieważ stanowiąc niezbywalny przedmiot własności Skarbu Państwa (tzw. górniczej), mogą być one przecież przedmiotem koncesji, której udzielenie nie może zostać uzależnione od posiadania przez wnioskodawcę (spółkę) wyłącznie polskiego kapitału. Rolę i rangę strategicznych zasobów naturalnych należałoby więc widzieć nie tyle w aspekcie ideowym (nacjonalistycznym), lecz aspekcie użytkowym, za pośrednictwem pełnionych przez nie usług ekosystemowych. Postulat ten ma znaczenie praktyczne, ponieważ 60\% światowych ekosystemów uległo degradacji lub jest niewłaściwie wykorzystywanych ${ }^{47}$, więc ich racjonalne użytkowanie powinno wysuwać się na plan pierwszy. Oznacza

45 http://www.klub.platforma.org/aktualnosci,article,propozycjazmian-w-konstytucji-rp-dotyczaca-lasow-pa--stwowych--wideo-,2446.html [22.02.2014].

46 B. Rakoczy, O potrzebie zmiany Konstytucji Rzeczypospolitej Polskiej w zakresie ochrony środowiska, „Studia Prawnicze KUL” 2009, nr 2-3, s. 167.

47 Komunikat Komisji do Parlamentu Europejskiego, Rady, Europejskiego Komitetu Ekonomiczno-Społecznego i Komitetu Regionów „Nasze ubezpieczenie na życie i nasz kapitał naturalny - unijna strategia ochrony różnorodności biologicznej na okres do 2020 r.”, COM/2011/0244 końcowy. 
to raczej konieczność patrzenia na zasoby strategiczne jako dobro wspólne współczesnego i przyszłych pokoleń, a nie wyłącznie dobro wspólne Polaków. Ma to znaczenie o tyle, że jak wzmiankowano we wstępnej części pracy - sposób formułowania pojęć z zakresu ochrony środowiska ma bezpośrednie przełożenie na jego stan i postawy obywatelskie.

\section{BIBLIOGRAFIA}

Bukowski Z. et al., Prawo ochrony środowiska. Komentarz, Warszawa 2013.

Encyklopedia ochrony środowiska, J. Ciechanowicz-McLean (red.), Warszawa 2009.

Giddens A., Nowe zasady metody socjologicznej, Kraków 2001.

Górski M. et al., Prawo ochrony środowiska. Komentarz, Warszawa 2011.

Gruszecki K., Prawo ochrony środowiska. Komentarz, Warszawa 2008. Kenig-Witkowska M.M., Międzynarodowe prawo środowiska. Wybrane zagadnienia systemowe, Warszawa 2011.

Olaczek R., Milenijna Ocena Ekosystemów - czy nowy Raport U Thanta?, [w:] Contemporary trends of botanical research - on profesor Hanna Piotrowska 80th birthday anniversary, „Acta Botanica Cassubica" 6/2006.

Paczuski R., Prawo ochrony środowiska, Bydgoszcz 2000.

Prawo ochrony środowiska, M. Górski (red.), Warszawa 2009.

Radecki W., Prawo towieckie. Komentarz, Warszawa 2007.

Rakoczy B., O potrzebie zmiany Konstytucji Rzeczypospolitej Polskiej w zakresie ochrony środowiska, „Studia Prawnicze KUL” 2009, nr 2-3.

Rakoczy B., Funkcjonowanie leśnych regulacji prawnych $w$ układach międzysektorowych, „Przegląd Prawa Ochrony Środowiska” nr 4/2013.

Ryszawska B., Zielona gospodarka - teoretyczne podstawy koncepcji i pomiar jej wdrażania w Unii Europejskiej, Wrocław 2013.

Scheuer B., Aksjologiczny kontekst ekonomicznych problemów gospodarowania zasobami środowiskowymi, [w:] Zrównoważony rozwój doświadczenia polskie i europejskie, J. Czaja (red.), Nowa Ruda 2005.

Steciąg M., Stowa-klucze w ekologii i ich krytyka z pespektywy ekolingwistycznej, „Problemy Ekorozwoju” 2009, nr 2. 
Szachułowicz J., Prawo wodne. Komentarz, Warszawa 2007.

Śliwiński A., Co się dzieje z polskimi zasobami naturalnymi?, „Biuletyn Europejskiego Monitora Ekonomicznego" nr 9/2009.

\section{Kontakt e-mail:}

Anna Haładyj - ahaladyj@kul.pl

Jacek Trzewik - trzewik@kul.pl 